\title{
PENGARUH MODEL PEMBELAJARAN CORE DENGAN STRATEGI KONFLIK- KOGNITIF TERHADAP KEMAMPUAN PEMAHAMAN SISWA SMP
}

\author{
Nora Susilowaty \\ Universitas Advent Indonesia Program studi Pendidikan Matematika \\ susilowatynora@gmail.com
}

\begin{abstract}
Abstrak Penelitian ini bertujuan untuk mengetahui peningkatan kemampuan pemahaman matematis siswa yang menerapkan pembelajaran CORE dengan strategi konflik kognitif dan pembelajaran konvensional, serta untuk mengetahui seberapa besar pengaruh pembelajaran CORE dengan strategi konflik kognitif terhadap kemampuan pemahaman matematis siswa. Penelitian ini merupakan penelitian kuasi eksperimen atau aksperimen semu dengan desain kelompok kontrol non-ekuivalen. Pelaksanaan penelitian ini dilakukan pada siswa kelas VIII di salah satu SMP Negeri di Cimahi. Soal kemampuan pemahaman matematis pada materi bangun ruang sisi datar yang diberikan kepada siswa telah diujicobakan dan memenuhi karakteristik untuk digunakan dalam penelitian seperti validitas, reliabilitas, daya pembeda dan tingkat kesukaran. Analisis data kuantitatif dilakukan dengan menggunakan uji t, sedangkan analisis data kualitatif dilakukan secara deskriptif. Hasil penelitian ini adalah siswa yang mendapatkan pembelajaran model CORE dengan strategi konflik kognitif peningkatan kemampuan pemahaman matematisnya lebih baik secara signifikan dibandingkan dengan siswa yang pembelajarannya menggunakan pembelajaran konvensional, dan pembelajaran CORE dengan strategi konflik kognitif sangat berpengaruh terhadap kemampuan pemahaman matematis siswa.
\end{abstract}

Kata kunci: Pembelajaran Model CORE, Strategi Konflik Kognitif, Pemahaman Matematis.

\section{PENDAHULUAN}

Kemampuan pemahaman matematik adalah salah satu kemampuan yang diajarkan disekolah dan harus dimiliki oleh siswa. National Council Teacher of Mathematics (2000) menguatkan pentingnya pemahaman matematis terlihat dari dimasukkan kemampuan tersebut sebagai standar proses dalam Curriculum and Evaluation Standars for School Mathematics (CEESM), maupun dalam Principles and Standars for School Mathematics (PSSM). Hasil penemuan Setiadi (2013) tentang kemampuan pemahaman matematis diperoleh bahwa rataan pencapaian skor postes kemampuan pemahaman siswa yang memperoleh pembelajaran dengan pendekatan probing-prompting sebesar $65,68 \%$ dari skor maksimum. Rataan skor kemampuan pemahaman siswa yang memperoleh pembelajaran biasa sebesar 53,63\%. Hal ini mengindikasikan bahwa kemampuan pemahaman siswa perlu ditingkatkan lagi. Sari dkk (2014) menemukan bahwa kekeliruan siswa dalam memahami masalah, model matematis yang tidak sesuai permasalahan, dan tidak mengecek kembali jawaban pada permasalahan asal menjadi faktor utama penyebab gagalnya siswa menyelesaikan masalah yang diberikan. Siswa melakukan pengecekan hanya jika mereka ragu dengan hasil yang diperoleh.

Berkaitan dengan upaya menciptakan pembelajaran yang mendukung tumbuh kembangnya kemampuan matematis siswa dalam belajar matematika, seyogyanya guru memperhatikan perbedaan karakteristik setiap siswa. NCTM dalam dokumen Professional Standards for Teaching Mathematics 
tahun 1991 (Wahyudin, 2008) menyatakan bahwa, perbedaan yang dimiliki siswa seperti latar belakang, kemampuan, minat, dan sebagainya berimplikasi pada pertimbangan yang ditempuh guru dalam menerapkan pembelajaran matematika di kelas.

Penggunaan sumber belajar yang kurang efektif, cara mengajar yang hanya terpaku pada buku pelajaran dan diajarkan melalui metode yang kurang melibatkan keaktifan siswa menyebabkan timbulnya konflik dalam pemahaman siswa, karena mereka masih ragu mengenai kebenaran dari materi yang sedang dibahas atau yang sedang dijelaskan oleh guru di dalam kelas, sehingga siswa dituntut untuk mencari kebenaran dari suatu konsep itu sendiri. Sehingga konflik mental pun muncul, dengan beberapa pilihan keputusan yaitu mempercayai apa yang dikatakan orang dan menyimpan pengetahuan lama (tanpa mengubahnya sehingga tetap utuh), atau mempertimbangkan kemungkinan bahwa sudut pandang lain terhadap situasi yang sama juga diterima (Given, 2002).

Menghadapkan siswa pada gagasan atau situasi baru yang menurut persepsinya bertentangan dengan pemahaman sebelumnya, maka setelah melakukan diskusi, tanya jawab dan demonstrasi atau eksperimen yang rasional dan masuk akal, memicu proses reorganisasi dan rekontruksi konsepkonsep dalam struktur kognitifnya, sehingga konsep yang baru dapat diterima siswa. Dengan demikian dibutuhkan sebuah strategi pembelajaran yang dapat memberi banyak kesempatan kepada siswa untuk dapat memperbaiki miskonsepsinya sebelum dia mempelajari konsep dengan tingkat yang lebih tinggi. Secara spesifik Berg (1991) dalam penelitiannya menyatakan strategi konflik kognitif dalam pembelajaran matematika cukup efektif untuk mengatasi miskonsepsi pada siswa dalam rangka membentuk keseimbangan ilmu yang lebih tinggi. Strategi konflik kognitif merupakan strategi pengubahan konseptual (conceptual change strategy) yang memungkinkan dapat merubah stabilitas miskonsepsi-miskonsepsi siswa untuk menuju konsepsi ilmiah.

Selain itu, agar strategi konflik kognitif tersebut dapat berjalan dengan baik, maka harus digunakan metode pembelajaran yang tepat guna lebih meningkatkan kemampuan pemahaman. Dalam melaksanakan penelitian ini, peneliti menggunakan model pembelajaran CORE yang bertujuan membantu siswa agar lebih memahami suatu topik atau konsep dalam pelajaran matematika.

Model CORE adalah suatu model pembelajaran yang memiliki empat aspek yaitu: Connect (C) merupakan kegiatan bertujuan untuk menghubungkan pengetahuan siswa yang telah ada dengan pengetahuan sebelumnya; Organize $(O)$, merupakan kegiatan untuk mengorganisasi ide-ide dan pengetahuan yang ada untuk memahami materi yang dilakukan dengan cara berdiskusi dengan teman sekelompoknya; Reflect $(R)$, merupakan kegiatan refleksi mengenai materi yang telah dipahami siswa; Extend $(E)$, merupakan kegiatan untuk mengembangkan, memperluas, menggunakan dan menemukan menurut Miller \& Calfee (2004).

Aspek-aspek yang terdapat dalam model CORE akan melatih siswa untuk melakukan berbagai aktifitas yang akan meningkatkan kemampuan pemahaman. Siswa dituntut untuk mampu 
mendapatkan informasi, menghubungkan berbagai informasi kemudian menjelaskannya didepan kelas dengan cara berdiskusi kemudian merefleksi konsep yang diperoleh siswa dan melakukan berbagai kegiatan untuk memperluas pengetahuan yang telah diperoleh.

Adapun masalah yang diangkat dalam penelitian ini sebagai berikut: (1) Apakah peningkatan kemampuan pemahaman siswa yang memperoleh pembelajaran model CORE dengan strategi konflik kognitif lebih baik daripada siswa yang memperoleh pembelajaran secara konvensional? (2) Seberapa besar pengaruh model pembelajaran CORE dengan strategi konflik kognitif terhadap peningkatan kemampuan pemahaman matematis siswa?

\section{METODE PENELITIAN}

Penelitian yang dilakukan menggunakan desain penelitian kuasi ekperimen, dengan desain kelompok kontrol non ekuivalen yang merupakan bagian dari bentuk kuasi eksperimen. Penelitian melibatkan dua kelas, yaitu kelas eksperimen dan kelas kontrol. Kelas eksperimen adalah kelas yang memperoleh pembelajaran model CORE dengan strategi konflik kognitif dan kelas kontrol adalah kelas yang memperoleh pembelajaran secara konvensional. Populasi dalam penelitian ini adalah seluruh siswa di salah satu SMP Negeri di Cimahi Bandung. Sampel dalam penelitian ini adalah siswa kelas VIII. Pemilihan kelas didasarkan atas pertimbangan bahwa siswa kelas VIII dianggap peneliti telah memenuhi prasyarat yang cukup untuk menjadi objek penelitian dan terkait dengan pemilihan materi pembelajaran. Teknik pengambilan sampel yang digunakan peneliti adalah teknik purposive sampling karena peneliti hanya mengambil sampel dari kelas-kelas yang sudah terbentuk berdasarkan pertimbangan guru matematika disekolah tersebut.

Penelitian dilaksanakan dengan menggunakan dua jenis instrumen yaitu instrumen tes dan instrumen non tes. Instrumen tes yaitu tes kemampuan pemahaman dan pemecahan masalah matematis yang disajikan sebagai pretes dan postes. Instrumen non tes yaitu data aktivitas guru diperoleh melalui lembar observasi dan pedoman wawancara siswa. Hasil observasi diolah secara deskriptif. Sedangkan data kuantitatif diperoleh dari hasil uji coba instrumen dan hasil pretes, postes, n-gain kemampuan pemahaman matematis. Selanjutnya untuk pengolahan data kuantitatif menggunakan bantuan program SPSS 23 for windows dan Microsoft Excel 2007. Data tersebut didapat dari 72 orang siswa yang terdiri dari 36 siswa kelas eksperimen yang mendapat pembelajaran CORE dengan strategi konflik kognitif dan 36 siswa kelas kontrol yang mendapat pembelajaran konvensional 


\section{HASIL PENELITIAN DAN PEMBAHASAN}

\section{Kemampuan Pemahaman Matematis}

Adapun data peningkatan kemampuan pemahaman hasil belajar siswa dapat dilihat pada

Tabel 1 berikut:

Tabel 1 Statistik Deskriptif Peningkatan kemampuan Pemahaman Matematis

\begin{tabular}{|l|c|c|c|c|c|c|}
\hline \multirow{2}{*}{ Nilai } & \multicolumn{3}{|c|}{ Kelas CORE } & \multicolumn{3}{c|}{ Kelas Konvensional } \\
\cline { 2 - 7 } & $\mathrm{N}$ & $\bar{x}$ & $\mathrm{SD}$ & $\mathrm{N}$ & $\bar{x}$ & SD \\
\hline Pretes & 36 & 5,94 & 1,89 & 36 & 5,03 & 2,43 \\
\hline Postes & 36 & 12,47 & 2,18 & 36 & 10,63 & 2,45 \\
\hline N-gain & 36 & 0,66 & 0,23 & 36 & 0,55 & 0,195 \\
\hline \multicolumn{8}{|c|}{ Skor Maksimum Ideal =16 } \\
\hline
\end{tabular}

Berdasarkan data tersebut dapat diketahui bahwa nilai rataan pretes kelas pembelajaran CORE yaitu 5,94 dan kelas pembelajaran konvensional 5,03 yang menunjukkan kedua kelas tidak jauh berbeda. Dari data postes diketahui nilai rataan postes kelas pembelajaran CORE 12,47 lebih tinggi dibandingkan rataan kelas pembelajaran konvensional yaitu 10,63. Kemudian skor pretes dan postes tersebut dianalisis, namun sebelum data dianalisis terlebih dahulu dilakukan uji prasyarat analisis yaitu uji normalitas dan uji homogenitas data pretes dan postes.

Tabel 2 Data Hasil Uji Normalitas Skor Pretes dan Postes Pemahaman Matematis

\begin{tabular}{|l|l|l|l|l|l|}
\hline \multirow{2}{*}{ Hasil } & \multirow{2}{*}{ Kelas } & \multicolumn{3}{|c|}{ Shapiro-Wilk } & \multirow{2}{*}{ Kesimpulan } \\
\cline { 3 - 5 } & & Statistik & Df & Sig & \\
\hline Pretes & CORE & 0,949 & 36 & 0,100 & $\mathrm{H}_{0}$ diterima \\
\cline { 2 - 5 } & Konvensional & 0,960 & 36 & 0,222 & $\mathrm{H}_{0}$ diterima \\
\hline Postes & CORE & 0,958 & 36 & 0,182 & $\mathrm{H}_{0}$ diterima \\
\cline { 2 - 5 } & Konvensional & 0,973 & 36 & 0,500 & $\mathrm{H}_{0}$ diterima \\
\hline
\end{tabular}

Pada Tabel 2 diperoleh bahwa skor pretes kemampuan pemahaman matematis siswa kelas pembelajaran CORE dan kelas pembelajaran konvensional memiliki nilai Sig. $>\alpha=0,05$ sehingga $\mathrm{H}_{0}$ diterima artinya sampel berasal dari populasi berdistribusi normal. Demikian juga pada skor postes kelas pembelajaran CORE dan kelas pembelajaran konvensional memiliki nilai Sig. $>\alpha=0,05$ sehingga $\mathrm{H}_{0}$ diterima artinya sampel berasal dari populasi berdistribusi normal. Kemudian dilakukan uji homogenitas data pretes dan postes seperti table 3. 
Tabel 3 Data Hasil Uji Homogenitas Varians Skor Pretes dan Postes

\begin{tabular}{|c|c|c|c|c|}
\hline Hasil & $\begin{array}{c}\text { Levene } \\
\text { Statistic }\end{array}$ & $D f$ & Sig. & Kesimpulan \\
\hline Pretes & 2,45 & 70 & 0,122 & $\mathrm{H}_{0}$ diterima \\
\hline Postes & 1.112 & 70 & 0,295 & $\mathrm{H}_{0}$ diterima \\
\hline
\end{tabular}

Berdasarkan Tabel 3 tampak bahwa nilai Sig. skor pretes sebesar 0,122 lebih besar dari $\alpha=$ 0,05 sehingga $\mathrm{H}_{0}$ diterima. Artinya skor pretes kemampuan pemahaman matematis siswa kelas pembelajaran CORE dan kelas pembelajaran konvensional memiliki varians yang homogen. Demikian juga nilai Sig. skor postes sebesar 0,295 lebih besar dari $\alpha=0,05$ sehingga $\mathrm{H}_{0}$ diterima. artinya skor postes kemampuan pemahaman matematis siswa kelas pembelajaran CORE dan kelas pembelajaran konvensional memiliki varians yang homogen. Selanjutnya dilakukan uji perbedaan rata-rata pretes dan postes dan hasilnya seperti tabel 4.

Tabel 4 Data Hasil Uji perbedaan Rataan Skor Pretes Kemampuan Pemahaman Matematis

\begin{tabular}{|c|c|c|c|}
\hline \multicolumn{2}{|c|}{$t$-test for equality of means } & \multirow{2}{*}{ Keterangan } \\
\hline $\mathrm{T}$ & $D f$ & Sig. (2-tailed) & \multirow{2}{*}{$\mathrm{H}_{0}$ diterima } \\
\hline 1,783 & 70 & 0,079 & \\
\hline
\end{tabular}

Pada Tabel 4 didapat nilai $p$-value atau Sig. (2-tailed) yaitu $0,079>$ dari $\alpha=0,05$. Hal ini menunjukkan bahwa $\mathrm{H}_{0}$ diterima, artinya bahwa kemampuan awal pemahaman matematis siswa yang menggunakan pembelajaran CORE dengan siswa yang menggunakan pembelajaran konvensional adalah sama.

Tabel 5 Data Hasil Uji Perbedaan Rataan Skor Postes Kemampuan Pemahaman Matematis

\begin{tabular}{|c|c|c|c|}
\hline \multicolumn{3}{|c|}{$t$-test for equality of means } & \multirow{2}{*}{ Keterangan } \\
\hline $\mathrm{t}$ & $d f$ & Sig. (2-tailed) & \multirow{2}{*}{$\mathrm{H}_{0}$ ditolak } \\
\hline 3,350 & 70 & 0,001 & \\
\hline
\end{tabular}

Berdasarkan Tabel 5 , didapat nilai $p$-value atau Sig. (2-tailed) yaitu $0,001<\alpha=0,05$. Hal ini menunjukkan bahwa $\mathrm{H}_{0}$ ditolak, sehingga dapat disimpulkan bahwa terdapat perbedaan skor postes yang signifikan antara kelas yang mendapatkan pembelajaran CORE dan kelas yang mendapatkan pembelajaran konvensional. 
Perbedaan inilah kemudian ditindak lanjuti dengan menghitung $N$-gain. Hal ini diperlukan untuk mengetahui seberapa besar peningkatan skor dari pretes ke postes. Diketahui bahwa rata-rata $\mathrm{N}$ gain kelas pembelajaran CORE 0,66 lebih tinggi dibandingkan rataan $\mathrm{N}$-gain pada kelas pembelajaran konvensional yaitu 0,55 . Meskipun $N$-gain dikedua kelas tersebut sama-sama berkategori sedang. Lebih lanjut dilakukan analisis uji perbedaan rata-rata terhadap $\mathrm{N}$-gain kemampuan pemahaman, namun sebelum dianalisis harus memenuhi prasyarat normalitas dan homogenitas.

Tabel 6 Data Hasil Uji Normalitas skor $N$-gain Pemahaman Matematis

\begin{tabular}{|l|l|c|c|l|}
\hline \multirow{2}{*}{ Kelas } & \multicolumn{3}{|c|}{ Shapiro-Wilk } & \multirow{2}{*}{ Kesimpulan } \\
\cline { 2 - 4 } & Statistik & Df & Sig & \\
\hline CORE & 0,943 & 36 & 0,061 & $\mathrm{H}_{0}$ diterima \\
\hline Konvensional & 0,972 & 36 & 0,476 & $\mathrm{H}_{0}$ diterima \\
\hline
\end{tabular}

Pada Tabel 6 terlihat bahwa skor N-gain kemampuan pemahaman matematis siswa kelas pembelajaran CORE memiliki nilai Sig.> $\alpha=0,05$ sehingga $\mathrm{H}_{0}$ diterima artinya data skor $\mathrm{N}$-gain kemampuan pemahaman matematis siswa kelas pembelajaran CORE berdistribusi normal. Demikian juga skor $\mathrm{N}$-gain kemampuan pemahaman matematis siswa kelas pembelajaran konvensional memiliki nilai Sig. $>\alpha=0,05$ sehingga $\mathrm{H}_{0}$ diterima artinya data skor $N$-gain kemampuan pemahaman matematis siswa kelas pembelajaran konvensional juga berdistribusi normal. Selanjutnya dilakukan uji homogenitas N-gain.

Tabel 7 Data Hasil Uji Homogenitas Varians Skor $N$-gain

\begin{tabular}{|c|c|c|c|c|}
\hline Hasil & Levene Statistic & $D f$ & Sig. & Kesimpulan \\
\hline$N$-gain & 0,030 & 70 & 0,863 & $\mathrm{H}_{0}$ diterima \\
\hline
\end{tabular}

Pada Tabel 7 terlihat bahwa skor $\mathrm{N}$-gain memperlihatkan nila Sig. sebesar 0,863 lebih besar dari $\alpha=0,05$ sehingga $\mathrm{H}_{0}$ diterima. Artinya skor $N$-gain kemampuan pemahaman matematis siswa kelas pembelajaran CORE dan kelas pembelajaran konvensional memiliki varians yang homogen.

Berdasarkan hipotesis bahwa Peningkatan kemampuan pemahaman matematis siswa yang mendapatkan pembelajaran CORE lebih baik daripada siswa yang mendapatkan pembelajaran konvensional, maka:

$\mathrm{H}_{0}: \mu_{C}=\mu_{K}$

(Tidak terdapat perbedaan peningkatan kemampuan pemahaman matematis siswa yang mendapat pembelajaran CORE dibandingkan dengan pembelajaran konvensional) 
$H_{1}: \mu_{C}>\mu_{K}$

(Peningkatan kemampuan pemahaman matematis siswa yang mendapat pembelajaran CORE lebih baik daripada siswa yang mendapat pembelajaran konvensional)

Keterangan :

$\mu_{C}=$ rataan skor $N$-gain kemampuan pemahaman matematis siswa yang mendapat pembelajaran CORE

$\mu_{K}=$ rataan skor $N$-gain kemampuan pemahaman matematis siswa yang mendapat pembelajaran konvensional

Kriteria pengujian hipotesis, $\mathrm{H}_{0}$ diterima jika $t_{\text {hitung }} \leq t_{(1-\alpha)}$, harga $t_{(1-\alpha)}$ diperoleh dari daftar distribusi $t$ dengan peluang $(1-\alpha)$, sebaliknya $\mathrm{H}_{0}$ ditolak pada harga lainnya. Derajat kebebasan $n_{1}+n_{2}-2=36+36-2=70$. Harga $t_{\text {tabel }(0,95)}=1,667$. Dengan menggunakan data $N$-gain pada kedua kelas, berikut disajikan rangkuman hasil uji perbedaan rataan skor $N$-gain pada taraf Sig. $\alpha=0,05$.

\section{Tabel 8 Data Hasil Uji Perbedaan Rataan Skor N-gain Kemampuan Pemahaman Matematis}

\begin{tabular}{|l|l|l|}
\hline Statistik & Nilai & Keterangan \\
\hline$T$ & 2,052 & \multirow{3}{*}{$\mathrm{H}_{0}$ ditolak } \\
\cline { 1 - 2 } Asymp. Sig. (2-tailed) & 0,044 & \\
\hline
\end{tabular}

Hasil uji Independent Sample T-tes didapat nilai p-value atau Sig. (2-tailed) yaitu 0,044 karena menggunakan uji satu pihak maka Sig. (1-tailed) yaitu $0,022<\alpha=0,05$ atau $t_{\text {hitung }}=$ $2,052>t_{\text {tabel }}=1,667$. Hal ini menunjukkan bahwa $\mathrm{H}_{0}$ ditolak sehingga terdapat perbedaan peningkatan kemampuan pemahaman matematis yang signifikan antara kedua kelas. Artinya peningkatan kemampuan pemahaman matematis siswa yang mendapatkan pembelajaran CORE lebih baik daripada siswa yang mendapatkan pembelajaran konvensional.

Artinya Hasil tersebut dapat menjawab hipotesis penelitian, yaitu secara signifikan peningkatan kemampuan pemahaman siswa yang belajarnya menggunakan model CORE dengan strategi konflik kognitif lebih baik dibandingkan siswa yang belajarnya secara konvensional.

Sebelumnya telah diketahui bahwa data skor N-gain kemampuan pemahaman matematis siswa kelas pembelajaran CORE dan kelas pembelajaran konvensional berdistribusi normal dan homogen. Perhitungan Effect size (Coe, 2002) dapat dilakukan untuk mengetahui besarnya pengaruh pembelajaran CORE terhadap peningkatan kemampuan pemahaman matematis. Hasil perhitungan Effect size disajikan pada Tabel 9 
Tabel 9 Hasil Perhitungan Effect Size N-gain kemampuan Pemahaman Matematis

\begin{tabular}{|c|c|c|c|c|}
\hline Hasil & Kelas & $\bar{x}$ & SD & Effect Size \\
\hline \multirow{2}{*}{$N$-gain } & CORE & 0,66 & 0,23 & 0,57 \\
\cline { 2 - 4 } & Konvensional & 0,55 & 0,19 & \\
\hline
\end{tabular}

Berdasarkan hasil perhitungan Effect size pada Tabel 9 besarnya pengaruh pembelajaran CORE dengan strategi konflik kognitif terhadap peningkatan kemampuan pemahaman matematis siswa diperoleh nilai sebesar 0,57 . Hal ini berarti sebanyak $69 \%$ siswa yang mendapat pembelajaran konvensional memiliki kemampuan pemahaman matematis dibawah siswa yang mendapat pembelajaran CORE. Berdasarkan klasifikasi nilai ini dapat diinterpretasikan bahwa pengaruh pembelajaran CORE dengan strategi konflik kognitif menghasilkan peningkatan dari $69 \%$ sampai $73 \%$, kebanyakan sekolah mengkategorikan nilai ini sebagai peningkatan yang cukup besar.

Hasil wawancara menunjukkan bahwa hampir seluruh siswa yang diwawancarai menyatakan merasa nyaman dan menjadi lebih senang belajar matematika. Siswa lebih menyukai belajar bersama kelompok daripada belajar sendiri terutama pada saat menghadapi permasalahan yang cukup sulit, selain itu siswa juga mengatakan bahwa soal-soal latihan yang diberikan cukup menantang. Siswa juga setuju bahwa dengan berkelompok mereka bisa berbagi pengetahuan. Sebagian siswa setuju bahwa waktu yang diberikan untuk mengerjakan LAS cukup, namun sebagian siswa lainnya juga mengaku bahwa waktu yang diberikan tidak cukup.

\section{PENUTUP}

\section{Kesimpulan}

1. Peningkatan kemampuan pemahaman matematis siswa yang mendapat model pembelajaran CORE dengan strategi konflik kognitif lebih baik daripada siswa yang mendapat pembelajaran konvensional

2. Pembelajaran model CORE dengan strategi konflik kognitif berpengaruh cukup besar terhadap peningkatan kemampuan pemahaman matematis siswa

\section{Saran}

Berdasarkan pada hasil analisis data penelitian, selanjutnya dikemukakan saran-saran sebagai berikut:

1. Model pembelajaran CORE dapat dijadikan salah satu pilihan pembelajaran untuk mengembangkan kemampuan pemahaman matematis 
2. Guru perlu memilih topik-topik esensial yang akan diajarkan dan memperhitungkan waktu ketika menggunakan pembelajaran CORE dengan strategi konflik kognitif daripada pembelajaran konvensional, sehingga topik-topik itu dapat dipahami lebih mendalam

3. Perlu dikembangkan bahan ajar dan soal-soal untuk meningkatkan kemampuan berpikir tingkat tinggi, agar siswa terbiasa mengerjakan soal-soal tersebut sehingga dapat meningkatkan kemampuan pemahaman matematis siswa

4. Para peneliti selanjutnya kiranya dapat menerapkan model pembelajaran CORE dengan strategi konflik kognitif pada pokok bahasan yang berbeda serta dapat mengembangkan aspek kemampuan tingkat tinggi yang lain misalnya berpikir kritis matematis

\section{DAFTAR PUSTAKA}

Badan Standar Nasional Pendidikan. (2006). Standar Isi untuk Satuan Penddikan Dasar dan Menengah.

Berg, Enwe V.D. 1991. Miskonsepsi, Fisika dan Remidiasi. Salatiga: Universitas Kristen Satya Wacana

Coe, R. (2002). It's The Effect Size, Stupid: What Effect Size is and Why It is Important. Paper

Presented at the British Educational Research Association Annual Conference, Exeter, 12 14 September 2002.

Given, B.K .(2002). Teaching to the Brain's Natural Learning System: Alexandria, VA: Association for Supervision and Curriculum Depelovment

Miller, R, G., \& Calfee, R, C. (2004). Making Thinking Possible: A Methode to Encourage Science Writing in The Upper Elementry Grades. Article in Science and Children,

25.[Online].Tersedia: www.raxannegmiller.com/.../Making\%20Thinking\%20Visible.pdf.

NCTM. (2000). Curriculum and Evaluation Standards for School Mathematics. Reston, VA :

\section{NCTM}

Sari, S., dkk. (2014). Pengaruh Pendekatan Pembelajaran Berbasis Masalah Terhadap Kemampuan Pemecahan Masalah Matematika Sswa Kelas VIII SMP Negeri I Padang Tahun Pelajaran 2013/2014. Jurnal Pendidikan Matematika Vol 3 No 2 Part 1: hal 54-59.

Setiadi, A. (2013). Meningkatkan Kemampuan Pemahaman dan Penalaran Matematis Siswa SMA melalui pendekatan probing-prompting. Tesis: UPI. Tidak diterbitkan

Wahyudin. (2008). Pembelajaran dan Model-Model Pembelajaran, Pelengkap untuk Meningkatkan Kompetensi Pedagogis Para Guru dan Calon Guru Profesional. 